\title{
On Issues of Labelling in the Dictionnaire Français-Mpongwé: A Case-study
}

\author{
P.A. Mavoungou, Department of Linguistics, Omar Bongo University, \\ Libreville, Gabon (moudika2@yahoo.fr)
}

\begin{abstract}
Dictionaries contain lexicographic data whose occurrence is restricted to certain geographical areas, subject fields, professions, etc. It is part of the duties of the lexicographer to give an account of such deviations to ensure a successful retrieval of the information on the part of the user. This contribution presents a discussion on labelling issues in the Dictionnaire FrançaisMpongwé. Although the main focus is on the presentation of different types of labelling as well as problems in labelling, textual condensation procedures and mediostructural representations (together with some aspects of the user perspective) are also critically evaluated. It is shown that these procedures reveal some inconsistencies which are not accounted for in the outer texts (front matter and back matter texts) of the dictionary. Finally suggestions are made for the improvement of the access structure of this dictionary.
\end{abstract}

Keywords: LABELS, TEXTUAL CONDENSATION, MEDIOSTRUCTURAL REPRESENTATION, ACCESS STRUCTURE, BORROWING, OUTER TEXTS, FRONT MATTER, BACK MATTER, USER PROFILE, METALEXICOGRAPHY

Résumé: À propos de quelques questions d'étiquetage dans le Dictionnaire Français-Mpongwé: un cas à l'étude. Les dictionnaires contiennent des données lexicographiques dont l'occurrence est restreinte à une région géographique donnée, un champ de connaissance, une profession, etc. Il est du devoir du lexicographe de prendre en compte ces déviations afin d'assurer un transfert d'information positif au niveau de l'utilisateur. La présente contribution présent une discussion sur les problèmes d'étiquetage dans le Dictionnaire Français-Mpongwé. Bien que le principal centre d'intérêt se situe au niveau de la présentation des différentes catégories d'étiquettes ainsi que les problèmes d'étiquetage, les procédés de condensation textuelles et les représentations mediostructurelles (accompagnées de quelques aspects relatifs aux utilisateurs du dictionnaire) sont également critiquement évalués. Il est démontré que ces procédés révèlent quelques inconsistances qui ne sont pas rendues au niveau des textes externes (prétextes et posttextes) du dictionnaire. Finalement, des suggestions sont faites dans le sens de l'amélioration de la structure d'accès de ce dictionnaire.

Mots-clés: ETIQUETTES, CONDENSATION TEXTUELLE, REPRÉSENTATION MEDIOSTRUCTURELLE, STRUCTURE D'ACCÈS, EMPRUNT, TEXTES EXTERNES, PRÉ-TEXTES, POSTTEXTES, PROFILE DE L'USAGER, METALEXICOGRAPHIE

\section{Introduction}

Mpongwe $\underline{e}^{1}$ is one of the six dialects of Omyene, the home language of five per 
cent of the population of Gabon. It is spoken in Libreville as well as on the island of Pointe-Dénis.

The Dictionnaire Français-Mpongwé by Raponda-Walker is a monodirectional publication with French as source language and Mpongwe as target language. It was published for the first time during 1930-1934 by the Imprimerie de la Libre Lorraine in Metz. In 1961, 27 years later, the dictionary was published in the reverse direction French-Mpongwe by the Imprimie Saint Paul in Brazzaville. This version of the dictionary has since then been reprinted in 1995 under the auspices of the Raponda-Walker Foundation. The last version comprises some 8000 articles arranged alphabetically according to the word tradition. The first part is the central word list, the dictionary proper, while the back matter or the second part of the dictionary contains an exposition of Mpongwe grammar (cf. Nyangone Assam and Mavoungou 2000).

The edition of 1961 was released when the compiler Raponda-Walker was already 90 years old. J. Adam, in the preface to this edition, is correct when stating that one needs much courage, good health and a good memory to carry out such a task.

The compilation of any dictionary has to take the needs and reference skills of the intended target user groups into account (cf. Hartmann 1989: 103). Although the introductory notes of the Dictionnaire Français-Mpongwé does not contain explicit reference to its target users, it is aimed at the average member of the Mpongwe speech community. It can be assumed that this target user group will not have a sound knowledge of dictionary use and therefore will need more assistance to cope successfully with the data presented in the dictionary. Moreover, the extent to which these data should be treated has to be determined by the needs and reference skills of the target users of the dictionary. From these assumptions one of the lexicographer's biggest tasks will be to make the product user-friendly.

\section{Labelling, inconsistent labelling and the absence of outer texts in the frame structure}

Dictionaries should be a reflection of the lexicon of a given language. Moreover, dictionaries contain lexicographic data whose occurrence is restricted to certain geographical areas, subject fields, professions, etc. For example, in any bilingual or multilingual dictionary with English as the treated language, the focus should be on one variety of English, e.g. British or American. But when including lexical items restricted to a variety exclusively used by the target users of the dictionary, the lexicographer should indicate this restricted usage by employing a system of geographical labels. With regard to lexicographic studies that have so far dealt with labelling issues, one can roughly classify lexicographers' viewpoints into three approaches. Some believe that lexicographic labels may be divided into four main categories, namely stylistic, geo- 
graphical, temporal, and sphere of usage labels. Labels in the first category are used to indicate style levels, e.g. formal, popular or slang. The second category deals with the so-called diatopic or regional labels such as American English, British English or South African English. Labels in the third category have a diachronic function. They are temporal labels, i.e. archaic, historical or obsolete. Sphere of usage labels are labels indicating use in a special field of activity. Labels such as lexicography, physics and law fall in this category.

Further types include labels indicating attitude or connotation (e.g. derogatory, offensive or obscene), labels indicating frequency (e.g. seldomly used) and labels of borrowing (e.g. loanword) (Bureau of the WAT 1999: 10-13). Contrary to this viewpoint, Landau (1991: 217-218) distinguishes eight groups of lexicographic labels, namely: labels indicating currency or temporality (old-fashioned, dated, archaic, obsolete, old use), labels indicating regional or geographic variations (U.S., British, Canadian, Australian, New Zealand, South African, etc.), labels indicating technical or specialized terminology (astronomy, chemistry, physics, sports, etc.), labels indicating restricted or taboo sexual and scatological usage (offensive, taboo, vulgar, obscene, rude, etc.), labels for insulting terms (offensive, insult, disparaging, derogatory, disapproving, contemptuous, sexist, racist), labels for slang language (slang), labels indicating style (level), functional variety, or register (formal, written, informal, spoken, colloquial, (now rarely used) literary, historical, poetic, humorous, facetious, jocular, approving, euphemistic, baby talk or child's word), and labels indicating status or cultural level (nonstandard or not standard).

Another group of lexicographers (cf. Benson, Benson and Ilson 1986: 215216) indicates that labels under the heading 'stylistic labels' include among others derogatory, pejorative and offensive. This constitutes quite a different opinion compared to the WAT's classification in which labels such as derogatory, pejorative and offensive appear under the heading 'labels indicating attitude or connotation'.

Norri (1996: 1-29) addresses the issue of labelling in some British and American dictionaries. More recently, the same topic has again been discussed by Norri (2000: 71-106). In this new approach, she groups the 145 words of her corpus into seven headings, namely: (1) Labelling for words for nationalities, (2) Labelling for words denoting racial and cultural groups, (3) Labelling for words for people considered to be lacking in intelligence, (4) Labelling for words for deceitful people, (5) Labelling for words for sexual orientation, (6) Labelling for some derogatory words for women, (7) Labelling for some derogatory words for men.

Although this article aims at addressing labelling issues in the Dictionnaire Français-Mpongwé, textual condensation procedures and mediostructural representations (with the user-perspective as background) will necessarily come to the fore. The emphasis will be on labels of borrowing, part of speech labels, stylistic labels, labels for special fields of activity and labels conveying information on pragmatics, syntax and semantics. 


\subsection{Labels of borrowing}

Tables 1 and 2 contain examples of labels of borrowing used in the Dictionnaire Français-Mpongzé.

\begin{tabular}{|l|l|l|l|}
\hline entries & labels & $\begin{array}{l}\text { source lan- } \\
\text { guage form }\end{array}$ & $\begin{array}{l}\text { source } \\
\text { language }\end{array}$ \\
\hline ekwèrè & (fang) & unknown & Fan \\
\hline kado & (néol.) & cadeau & French \\
\hline kalavati & (néol.) & cravate & French \\
\hline keretyè & (néol.) & chrétien & French \\
\hline kopi & (néol.) & copie & French \\
\hline kurusa & (néol.) & cruz & Portuguese \\
\hline krusu & (néol.) & cruz & Portuguese \\
\hline lakóli & (néol.) & colle & French \\
\hline lakrwa & (néol.) & croix & French \\
\hline lamèsi & (néol.) & messe & French \\
\hline laso & (néol.) & chaux & French \\
\hline mangazè & n.l. & magasin & French \\
\hline marabu & n.l. & marabout & French \\
\hline
\end{tabular}

\begin{tabular}{|l|l|l|l|}
\hline entries & labels & $\begin{array}{l}\text { source lan- } \\
\text { guage form }\end{array}$ & $\begin{array}{l}\text { source } \\
\text { language }\end{array}$ \\
\hline mero & (néol.) & numéro & French \\
\hline molata & n.l. & mulato & Portuguese \\
\hline pese & (néol.) & péché & French \\
\hline póketi & (néol.) & poche & French \\
\hline pósi & (néol.) & poche & French \\
\hline semizi & (néol.) & chemise & French \\
\hline sigarèti & (néol.) & cigarette & French \\
\hline sigaro & (néol.) & cigare & French \\
\hline sokola & (néol.) & chocolat & French \\
\hline su & (néol.) & choux & French \\
\hline tizani & (néol.) & tisane & French \\
\hline tsatsópu & (néol.) & unknown & unknown \\
\hline
\end{tabular}

Convention: n.l. is short for not labelled.

Table 1: Examples of labels of borrowing used in the Dictionnaire Français-Mpongwé.

\begin{tabular}{|l|c|l|c|}
\hline entries & labels & $\begin{array}{l}\text { source lan- } \\
\text { guage form }\end{array}$ & $\begin{array}{l}\text { source } \\
\text { language }\end{array}$ \\
\hline bèlèti & $($ ang.) & bullet & English \\
\hline bóyi & - & boy & - \\
\hline fatere & - & factory & - \\
\hline fiva & - & fever & - \\
\hline kapina & - & carpenter & - \\
\hline keki & - & cake & - \\
\hline korèyi & - & corail & - \\
\hline kóltar & - & coltar & - \\
\hline meli & - & mail-steamer & - \\
\hline
\end{tabular}

\begin{tabular}{|l|l|l|c|}
\hline entries & labels & $\begin{array}{l}\text { source lan- } \\
\text { guage form }\end{array}$ & $\begin{array}{l}\text { source } \\
\text { language }\end{array}$ \\
\hline paléti & - & pilot & - \\
\hline patóni & - & patron & - \\
\hline pikóki & - & peacock & - \\
\hline pusi & - & pussy & - \\
\hline silipasi & - & slipper & - \\
\hline siti & - & sheet & - \\
\hline sitowa & - & store & - \\
\hline sópu & - & shop & - \\
\hline tikèti & - & kettle & - \\
\hline
\end{tabular}

Convention: a dash indicates identity with the form given in the preceding square.

Table 2: Examples of labels of borrowing used in the Dictionnaire Français-Mpongwé.

According to the system applied in Tables 1 and 2, it seems that the compiler wants to give an account of the item indicating the source language of the entry treated only for English. Many questions are likely to arise: Are the entries labelled (néol. $=$ néologisme/neologism) not accurate enough as compared to the one labelled (ang. = anglais/English)? Are these entries too recent in the system of Mpongwe to be labelled (from French)? A close look at RapondaWalker (1995: 138) leads us to the answer to these questions. In RapondaWalker's view, the term néologisme is a comprehensive name for a variety of linguistic phenomena, viz. corrupted European words, borrowed words and indigenous words having acquired a new meaning. 
From this definition, lexical items in Table 1 mainly fit into the categories of corrupted forms and loanwords. But this terminology is ambiguous and may confuse the user. As a matter of fact, Raponda-Walker first used the term néologisme in 1933. When the dictionary was published in 1961 the same terminology was again used. It is therefore also not surprising that nothing has been changed in the edition of 1995 under the auspices of the Raponda-Walker Foundation, for this is simply a reprint and not a revision. It is, however, confusing for the user because these lexical items which were labelled néologismes in 1961 may not be factually correct today. Objections can also be made with regard to the absence of labels at entries such as molata, mangazè and marabu as well as the lack of explanations in the user's guidelines as far as the system the lexicographer applied is concerned. The absence of a label is just as important as its presence. In other words, the absence of labels at these entries incorrectly indicates that they are indigenous to the Mpongwe dialect (cf. Bureau of the WAT 1999: 10 and 14).

\subsection{Part of speech labels}

In Table 3, the labels in capitals indicate parts of speech in the Dictionnaire Français-Mpongwé:

\begin{tabular}{|l|l|}
\hline part of speech labels & significations \\
\hline N. & Nom \\
\hline N. \& ADJ & Nom et Adjectif \\
\hline ADJ. & Adjectif \\
\hline ADJ. \& N. & Adjectif et Nom \\
\hline ADJ. NUM. & Adjectif numéral \\
\hline ART. & Article \\
\hline A. N. C. & Adjectif numéral cardinal \\
\hline ADJ. N. C. & Adjectif numéral cardinal \\
\hline A. N. O. & Adjectif numéral ordinal \\
\hline ADJ. POSS. & Adjectif possesif \\
\hline V. & Verbe \\
\hline V. A. & Verbe actif \\
\hline V. A. \& N. & Verbe actif et Nom \\
\hline V. N. & Verbe nominal \\
\hline V. N. \& A. & Verbe nominal et adjectif \\
\hline V. N. \& N. & Verbe nominal et Nom \\
\hline
\end{tabular}

\begin{tabular}{|l|l|}
\hline part of speech labels & significations \\
\hline V. PR. & Verbe pronominal \\
\hline V. IMP. & Verbe impersonnel \\
\hline V. D. & Verbe dérivé \\
\hline PR. IND. & Pronom indéfini \\
\hline PR. DEM. & Pronom démonstratif \\
\hline PRO. Démons. & Pronom démonstratif \\
\hline PRÉP. & Préposition \\
\hline PR. PERS. & Pronom personnel \\
\hline PR. PSS. & pronom possessif \\
\hline CONJ. & Conjonction \\
\hline ADV. & Adverbe \\
\hline ADV. LOC. & Adverbe locutionel \\
\hline L. ADV. & Locution adverbiale \\
\hline LOC. ADV. & Locution adverbiale \\
\hline INTERJ. & Interjection \\
\hline
\end{tabular}

Table 3: Part of speech labels used in the Dictionnaire Français-Mpongwé.

Apart from some minor inconsistencies (the part of speech labels Adjectif numéral cardinal, Pronom démonstratif and Locution adverbiale have two variants each), the main objection with regard to these labels is the absence of a metatext in the introductory section listing and explaining the part of speech labels to the target user. 


\subsection{Stylistic labels}

Stylistic labels mainly include labels indicating style levels (e.g. formal/informal, slang or vulgar/elevated, colloquial) and labels indicating frequency of usage (e.g. mostly used in the plural form or singular form, rare, etc.). This is illustrated by the examples under (1).

(1) machin N. (pop.) J'ai vu machin, my'adyena wónó. Un machin à nettoyer les bouteilles, mandè yi sogin'imbute.

méli-mélo $\quad$ N. (fam.) bindaka-bindaka.

In the examples under (1), the lexicographer uses the labels (pop.) and (fam.) to warn the user against the application of the lexical items machin and méli-mélo in formal conversation. In the treatment of the article of the lemma machin, in particular, the user is provided with co-text examples illustrating its typical use in local French. Each co-text example is followed by its translation equivalent in Mpongwe.

\subsection{Labels for special fields of activity}

Labels in this category identify the special area of knowledge to which a lemma or an entry applies:

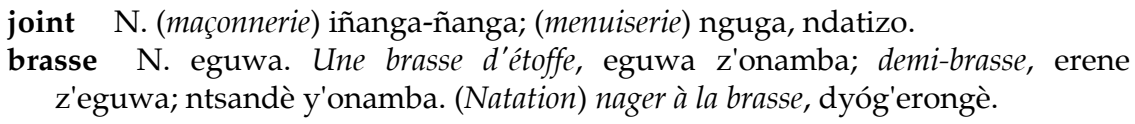
z'eguwa; ntsandè y'onamba. (Natation) nager à la brasse, dyóg'erongè.

Immediately after the lemma sign (in bold) and the part of speech indicator appears the label (maçonnerie) (masonry), followed by the translation equivalent (in italics) and another label (menuiserie) (joinery) plus its translation equivalents. Through the application of these labels, the user is immediately informed about the professional fields to which the lemma belongs. In the treatment offered in the article of the lemma brasse (cf. Hausmann and Wiegand 1989: 353), the user is provided with both macro- and microstructural data. The first data types are referred to as the comment on form (e.g. the lemma sign brasse and the item giving the part of speech, N.), whereas the second data categories are known as the comment on semantics (paraphrase of meaning/translation equivalent). The latter is divided into two sections. The first section deals with the typical use of the lemma brasse plus its co-text examples. The second section is introduced by a sphere of usage label (Natation) making the user aware of the specialised field (swimming) to which the lemma belongs.

\subsection{Labels conveying information on pragmatics, syntax and semantics}

The Dictionnaire Français-Mpongwé also makes use of italicised words in parenthesis after the lemma or an entry in order to convey information on pragmat- 
ics, syntax and semantics. This is illustrated by the examples in Table 4 and under (3).

\begin{tabular}{|r|l|l|}
\hline & Lemmata & Contextual data \\
\hline 1 & amphisbène & N. (serpent dit «double-tête») mbumba-ntse. \\
\hline 2 & ampoule & N. (cloque) iwowi. (Electrique) intsó ñi lambi. \\
\hline 3 & ascaride & N. (ver intestinal) ogola. \\
\hline 4 & candeur & N. (ingénuosité) mbondwè; (pureté d'âme), nkèrè y'orèmâa. \\
\hline 5 & cangue & N. (supplice) ompango. \\
\hline 6 & canicule & N. (époque des grandes chaleurs) enongo-nongo. \\
\hline 7 & cimeterre & N. (sabre recourbé) ambóndóngó m'okwara. \\
\hline 8 & cleptomanie & N. (manie du vol) nkanie y'idyufa. \\
\hline 9 & colonie & N. (possession) ntse yi re bóngo-pa. (Population) mbèì'iinóngó. \\
\hline 10 & digue & N. (chaussée) ogomba w'ado; (barrage de pêche) nkumba. \\
\hline 11 & éructation & N. (renvoie) mbyogo. \\
\hline 12 & famille & N. (sens large) mbuwe; (sens restreint) ngwèmo, inu. \\
\hline 13 & incessamment & ADV. (sans délai) du go tètètè vènó. \\
\hline 14 & mélopée & N. (chant monotone) orangwa-rangwo, ... \\
\hline 15 & patriarche & N. (chef de famille) onèró wi mbuwe; ... \\
\hline 16 & pou & N. (de tête) mbina; (de corps) mbanda; (de pubis) ndjili \\
\hline 17 & profane & N. (non initié) \\
\hline
\end{tabular}

Table 4: Italicised words in parenthesis used as labels in the Dictionnaire Français-Mpongwé.

(3) affection N. itónda; (en médecine) nkani.

affranchir V.A. (un esclave) dandun'osaka; (une lettre) postu'ezango.

S'affranchir, dandwa; un affranchi, olanduno.

Considering the data presented in Table 4, one can question the use of these contextual data in the form of labels since an explanation (cf. Zgusta 1987: 5) as given in the example in Table 5 below is particularly necessary if the translation equivalent offered is not an absolutely exact one. An entry like mbyogo, Table 4 number 11, is perhaps a unique translation equivalent of the French word éructation. It is an insertible equivalent (cf. Zgusta 1987: 5) and a priori does not need any gloss. The italicised explanation given in parenthesis is meant in the first place for speakers of French to help them disambiguate the meaning of the lemma éructation. But the entry mbyogo itself has both a translational and an explanatory power because it can be inserted into any co-text example of contemporary Mpongwe. The same line of argumentation holds true for the other members of Table 4 . With the entry (serpent dit «double-tête»), Table 4 number 1 , the user is referred to the denotatum. All these entries help the user both to contextualise and co-textualise. They have both an encoding and a decoding function. Further examples include those under (4).

(4) blé N. (farine de.), fariña y'atanga.

blesser V.A. bóndja. Blesser quelqu'un, bóndj'oma evora. (Fig.) Ce mot l'a blessé, igamba mè-nónó ñ'atuma ... 
borne N. (de pierre.) ido ñ'okao, elingilyo z'okao. (Par ext.) dépasser les bornes, pasiza.

In the article of the lemma blé, this is the information the user is expected to retrieve from the macro- and microstructural data presented: blé, noun whose typical syntagmatic pattern is farine de blé and whose translation equivalent in Mpongwe is fariña y'atanga. In the treatment of the articles of the lemmata blesser and borne, the user is provided with two kinds of semantic data. Subsection one contains the dominant sense of the lemmata (the one that would first occur to the target user) plus their co-text examples. Subsection two is introduced by the labels (Fig.) and (Par ext.) (also (sens restreint) and (sens large) in the article of the lemma famille, Table 4 number 12) denoting distinctions in meaning of the treatment units. Despite the absence of typographical structural markers (i.e. the diamond $\bullet$ or, as it seems to be the case in the dictionary, the dash -) or ordering devices, as far as this dictionary article is concerned, these labels also create divisions in the lexicographic text (cf. Hausmann and Wiegand 1989: 338-339). As such, they form part of the inner rapid access structure of a dictionary because the user is merely interested in the metaphorical use of the lemma and immediately gets the information about the meaning that is looked for and thus does not have to work through the entire article. This point is illustrated in the treatment of the article of the lemma partir:

$$
\begin{aligned}
& \text { partir V. N. kènda; dubwa. Partir à Kango, kènda go Kango. Partir de Néndé, } \\
& \text { dubwa go Néndé. Etant parti de là, ayè lubu gogo; ayè gogo Partir quelques } \\
& \text { minutes, kènd'ogèndó wa gore; pour revenir le même jour, Kènda kili. A partir } \\
& \text { d'aujourd'hui, avilo nèno winó, avil'owendja wa nènó. - L'Arambo part du } \\
& \text { Mont-bouët, olówi w'arambo wi pakilya g'Indóku. Le coup de fusil est parti tout } \\
& \text { seul, ndjali yakamba ou yabamina yomè. La foudre part des nuages, ndjalitowa } \\
& \text { yi pila go vindi. }
\end{aligned}
$$

From the typographical exposition applied in the example under (5), the user can retrieve information belonging to two different search areas. The first search zone is concerned with co-text examples in which the lemma typically occurs, whereas in the second search zone, the user is provided with additional competence examples taken from daily conversation.

Apart from using the dash as a typographical structural marker, others also come into play. Lemmata are printed in bold face, items giving the translation equivalents are printed in roman type and examples and meaning explanations in the source language (French) are given in italics. The presentation of the lemmata set apart typographically from the rest of the lexicographic text has much improved the access structure of the dictionary. Along with typographical structural markers non-typographical structural indicators are used to achieve a metacommmunicative function. Commas are used to separate translation equivalents of the same polysemous sense of the lemma, whereas semicolons separate translation equivalents representing different polysemous senses of the lemma (cf. Gouws 1999a: 12). As already mentioned, both typographical and non-typographical structural indicators have the same genuine purpose (as 
explained by Wiegand 1999: 299) of assisting the user in retrieving the relevant information as quickly as possible. Unfortunately, they are not explicitly explained in the introductory notes. Judging from these data, one would conclude that the dictionary is compiled for well-informed users, persons well familiar with dictionary-using skills. But since there is no metatext or outer text advising the target user how to use the dictionary, the well-devised microstructure of the dictionary is likely to be unknown to him/her.

From the system applied in the dictionary, it seems that the hyphen has a double function. Firstly it is used as a typographical structural marker as it occurs in the example under (5). But it is also used to substitute the lemma in the illustrative examples, functioning as a place-keeping symbol. Compare the following example from the dictionary:

$$
\text { aborder V. N. suma, dyèza. Aborder à Ovéndo - à l'île Perroquet, suma g'Ové- }
$$
ndo; dyèza go Mbini. Aborder une personne, susa gor'oma.

This use of textual condensation procedures also reveals some inconsistencies. Consider the following example in this respect:

bien N. mbya. Un homme de bien, om'ombya. Rendre le bien pour le mal, finizembya go mbe. Le bien public, mbya y'anaga waodu. (Richesses) tous ses biens, aniv'imè modu, sik'iyè yodu. Le bien d'autrui, ya yi ngani.

ADV. mbyambye, kwèkwè. Tu as bien agi, o denda mbyambye, o denda kwèkwè. Très bien, mbyambye polo. Mon fardeau est bien lourd, irwano ñami ñ'adiri polo. Bien des gens, anag'awenge, ntango anaga. Il y a bien un an, atweni ga ompuma. Tout va bien, zel'osâ̂u. Ou bien, ntsó.

L. CONJ. bien que, wanga go re, wanga go. Bien qu'il soit jeune, wanga go re yè ô̂wango. Bien qu'il pleuve, wanga go nóge ningo.

INTERJ. hé bien! qu'en dis-tu? o buya sè rèti! Eh bien! soit, mbuku!

The lemma bien is polyfunctional for it can be used as a noun, an adverb, a conjunction and an interjection. The following represents a partial, annotated structural graph of this article:

(8)

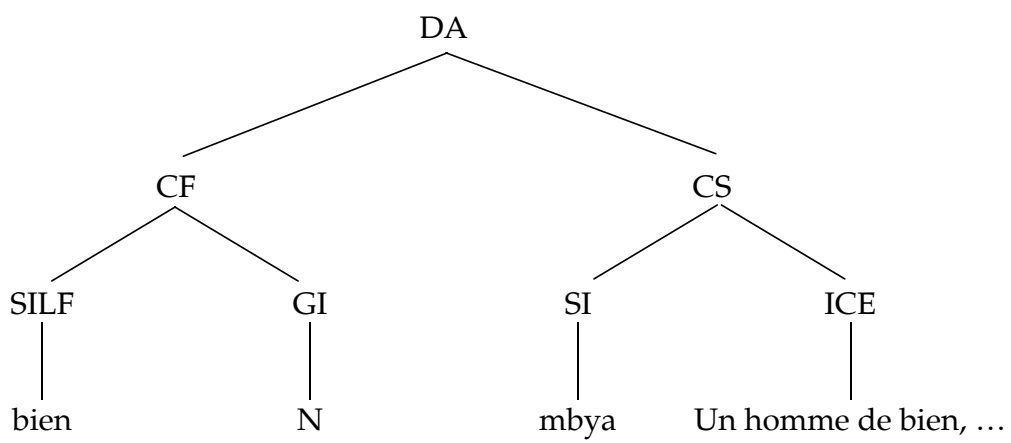

Abbreviations: $\mathrm{DA}=$ dictionary article; $\mathrm{CF}=$ comment on form; $\mathrm{CS}=$ comment on semantics; SILF = semantic item giving the lemma form; GI = grammatical item; $\mathrm{SI}=$ semantic item; ICE = item giving the competence example. 
What is interesting here is that the target language examples (in italics) function in a non-lemmatic addressing procedure. In other words, they are not addressed at the lemma but at the source language competence examples. Thus the latter become treatment units within the article. Furthermore, the system applied in the dictionary is dominated by the user perspective. In fact, the compiler does not make use of textual condensation devices, which consist of decreasing the data types in order to save space (cf. Gouws and Prinsloo 1997: 51-55). Employing a textual condensation approach, the compiler should have used the tilde $\sim$ or the dash - to substitute the lemma in the illustrative examples. By avoiding textual condensation procedures, the compiler has taken the needs and reference skills of the user of the dictionary into account. As a matter of fact, the user is not well familiar with dictionary-using skills. The way in which the compiler applied this system of textual condensation could have added to the predictability, systematicity and scientificity of the dictionary if it had been done consistently. Another area where the user profile also comes into play is the use of mediostructural representations. According to Gouws (1999a: 43), the mediostructure is "the system of cross-referencing which leads a user from a reference position to reference address". In the Dictionnaire Français-Mpongwé, it seems that the compiler only uses the external reference address. The following examples illustrate this point:

(9) (a) celui, celle, ceux, celles PR. DEMONS. oma, mongi. Celui ou celle qui a menti, oma w'awanoka. Ceux ou celles qui ont a menti, oma w'awanoka. Ceux ou celles qui ont volé, mongi w'adyufa. Celui-ci, oma winó; celui-là, oma wónó; ceux-ci, mongi sinó; ceux-là, móngi sónó. V. Grammaire.

(b) être V. DEF. (Se rend de différentes façons). Re Dieu est bon, Añambyè are ombya. Ils sont là-bas, wi re gonó.

- Bya. La journée sera mauvaise, owendja wi bya ombe. Ces enfants seront des paresseux, awana winó wi bya agera.

— Ni. C'est toi le voleur, ofe ni wè; o dyufa ni wè. Quelle est ta maison? n'agw'ó ni ye?

- Duo. Il était ici ce matin, aduo gunu ibanga. Je serai là-bas demain, m'be duo gogo mènè.

- Dwana. Ce village sera grand, nkala yinó yi be dwane mpolo. Sois tranquille, lwana kende-kende.

— Pegaga. J'étais couché, my'apegaga bu. Ils étaient à Sisè hier, w'avegagi dyao go Sisè.

- (est parfois sous-entendu). Je suis un Mpongwè. Vous êtes des imbéciles, myè om̂wo-Mpongwè anwè lèngèlè y'anaga. $C f$. Grammaire ...

In example (9)(a), the user is provided with the item giving the part of speech as well as the translation equivalents. Then follow the co-text examples in French (in italics) and their translation equivalents in Mpongwe (in roman). The article ends with a cross-reference entry in which the user is referred to the mini-grammar of the dictionary where grammatical data are discussed in more detail. The reference entry $V$. Grammaire (Voir Grammaire/See Grammar) con- 
sists of a reference marker $(V$.$) and an entry indicating the reference address$ (Grammaire) (cf. Gouws 1999b: 7). Here one also finds a new type of macrostructural ordering, namely a nested lexemic paradigm ${ }^{2}$. As far as this point is concerned, lexicographers usually make use of niching or nesting procedures. An example of the use of a sinuous lemma file which is very user-friendly ${ }^{3}$ occurs in Cassell's French-English/English-French Dictionary by J.C. Manchon $\left(1951^{5}\right)$. Manchon has interpreted the lemma sign celui as it occurs under (10) as a macrostructure with grouping.

celui (sə'lyi) demonst. pron. m. (fem. celle pl. ceux, celles) He, him; she, her; they, them; that, those. Ceux qui ont vécu avant nous, those who lived before us. celui-ci, celle-ci, This one, the latter; ceux-ci, celles-ci, these, the latter. celuilà, celle-là, That, the former; ceux-là, celles-là, those, the former. Aimez-vous mieux celui-ci?do you like this best? celui-ci est meilleur que celui-là,this is better than that; celui-là n'est pas si beau, that; one is not so fine. [Celui-ci relates to an object near the speaker; celui-là, to an object distant from him; or after two nouns already expressed, celui-ci refers to the last, celui-là to the first mentioned.]

Sublemmata celle, ceux and celles are listed according to their gender and number. Later in the article, the ordering of celui-ci, celle-ci, ceux-ci, celles-ci, and celui-là, celle-là, ceux-là, celles-là has not been done at random. Morphological considerations play an important role in the arrangement within this lemma cluster. In this nest, the compiler makes a distinction between demonstrative pronouns related to an object near the speaker and those related to an object distant from the speaker. The first category of demonstrative pronouns is given first. In the listing, priority is given to demonstrative pronouns with a masculine gender. Moreover, the singular form of the demonstrative pronoun dealt with comes first in the list, then followed by the plural form. The comment on usage at the bottom of the article given in square brackets is an example of a good lexicographic practice which contains useful information for the user.

In example (9)(b), the reference entry $C f$. is used instead of $V$. In addition, the article also displays features of textual condensation devices. Criticisms have already been made with regard to the absence of a user-driven approach as well as inconsistencies regarding the system the compiler applied. Front matter texts and back matter texts are not the sole reference address as far as mediostructural representations are concerned. In fact, mediostructural procedures usually include three categories, namely the internal reference address, the external reference address and the dictionary external reference address (cf. Gouws and Prinsloo 1998: 20-22). The article-internal cross-referencing functions within the boundaries of an article whereas the article-external crossreferencing refers a user to an entry in another article or another text in the dictionary (cf. Gouws 1999a: 43). The dictionary external reference address is especially useful to refer a user from a mini-grammar to a source outside the dictionary where a comprehensive account on grammatical issues can be found. 


\section{Improving the access structure of the dictionary}

As far as the access structure is concerned, a distinction is usually made between the outer and the inner access structure. The outer search path proceeds vertically through the carriers of guiding elements (i.e. from $A$ to $Z$ ) while the inner search path starts at the lemma and proceeds horizontally through the dictionary article (cf. Hausmann and Wiegand 1989: 338).

Changes can be made at the level of the access structure. For example, Gouws (1996: 21) points to the following: "The Reader's Digest Afrikaans-Engelse Woordeboek/English-Afrikaans Dictionary (hereafter abbreviated as RD) owes its poly-accessible character to the inclusion of additional outer access structures ... The original macrostructure of $\mathrm{RD}$ is presented in two columns occupying the centre of each page. An additional column is included on either side of the central word list." This metalexicographic innovation could be used to convey cultural or pragmatic information to the user as illustrated in the treatment of the article of the lemma marché in Table 5.

\begin{tabular}{|c|c|}
\hline $\begin{array}{c}\text { Ikasa, primitivement pont, jetée, a pris ul- } \\
\text { térieurement la signification de marché }\end{array}$ & $\begin{array}{c}\text { marché N. (lieu public) ikasa, igolino. Af- } \\
\text { fluer au marché, suzana g'ikasa, bengana }\end{array}$ \\
$\begin{array}{c}\text { public, parce que le premier marché } \\
\text { établi dans la colonie était installé sur } \\
\text { la jetée de Libreville (A. Raponda-Wal- } \\
\text { ker: Les langues } d u \text { Gabon, 1998, 148). }\end{array}$ & $\begin{array}{l}\text { (Transaction) igolo. Conclure un marché, } \\
\text { teniz'igolo, kol'igolo. A bon marché, igolo } \\
\text { iwaya, igolo ilèle. }\end{array}$ \\
\hline
\end{tabular}

Table 5: The treatment of the article of the lemma marché as it occurs in the Dictionnaire Français-Mpongwé.

This is the kind of presentation that may be used if changes to the central list of the existing dictionary is not possible in a revised reprint or reissue. A so-called "secondary macrostructure" may be introduced. Next to the previous macrostructure new data complementing or updating previous data may be added as demonstrated in the two columns of Table 5: the right column showing the previous macrostructure and the left column giving the new added macrostructure.

Instead of using metalexicographic innovations of the kind of the RD, one can also improve the access structure of the dictionary by means of inserted inner text blocks. Compare the treatment of the same lemma as it occurs in Table 6:

marché

Ikasa, primitivement pont, jetée, a pris ultérieurement la signification de marché public, parce que le premier marché établi dans la colonie était installé sur la jetée de Libreville (A. Raponda-Walker: Les langues du Gabon, 1998, 148).

Table 6: The treatment of the lemma marché by means of an inserted inner text block. 
Apart from the main text or central list of the dictionary, the entering of marché as part of the inserted inner text will give the work the feature of a poly-accessible dictionary. The user seeking the meaning of the lemma marché will proceed along the inner search path in order to find information regarding both the comment on form (mainly the item giving the part of speech) and the comment on semantics (e.g. translation equivalents and examples). However, if the user needs information of a pragmatic nature, he/she will have to consult the inserted inner text, which in this case is a secondary macrostructure or middle matter (cf. Hausmann and Wiegand 1989: 338). In addition, the treatment of lemmata such as moustiquaire, fourmis, parapluie, nappe de table, etc. can be improved by providing the user not with inserts but by making provision for short comments on pragmatics. Such comments on pragmatics can be found in Raponda-Walker (1933). This is relevant because these additional texts may help the user to disambiguate the meaning of the treated lemmata. They also provide the user with morphological and syntactical clues. In this way, the user will be well aware of the cultural value as well as the semantic load of the lexical items that he/she uses in his/her daily routine.

\section{Conclusion}

The intention of this article was to give an overview of issues relating to labelling in the Dictionnaire Français-Mpongwé. Lexicographic data whose occurrence is restricted to certain geographical areas, subject fields, professions, etc. are generally acknowledged in the dictionary. The use of contextual entries as well as labels in the dictionary articles does not only add to the predictability of the dictionary but it is also a user-driven approach. Apart from some shortcomings, the target user of the dictionary is consistently aided by guidelines enabling him/her to choose and use the right translation equivalent in the right context. However, Raponda-Walker's work has failed to supply lists of labels in the outer texts of the dictionary. The dictionary displays a well-devised access structure with a Mpongwe speaker in mind. The use of typographical and nontypographical structural markers, largely predictable, have improved the quality of the dictionary. There are still some shortcomings especially in the areas of textual condensation (lack of uniformity in the treatment) and mediostructural representations. When dealing with borrowed words, data categories regarding the donor language (i.e. the item giving the source language as well as the one giving the source language form) should be acknowledged in future (revised) editions. For example, if the word mangazè is proven to be a contemporary example of oral usage of the Mpongwe lexicon, then it has to be labelled as corrupted form of the French word magasin.

For all lexical items labelled in the dictionary as néologisme and anglais, research has to be conducted through fieldwork at grassroots level. A survey of these lexical items may improve the dictionary's standard with regard to its label policy. Labelling is the lexicographer's way of dealing with lexical items which deviate from the standard language. Therefore there is a need for accu- 
rate labelling. In addition, problems relating to labelling also include the absence of a clearly defined and consistent policy on labelling. Attempts should be made toward the standardisation of labels across dictionaries (cf. Bureau of the WAT 1999: 10 and 14).

\section{Endnotes}

1. The spelling used here is the official Gabonese spelling and not the traditional semiphonetic spelling employed by Guthrie, Jacquot, Kwenzi-Mikala and others. The underlined $\underline{e}$ and $\underline{n}$ represent $[\varepsilon]$ and $[\eta]$ respectively.

2. This information comes from Prof. R. H. Gouws (lectures).

3. It is user-friendly in the sense that the compiler has made the typographical presentation of the lexicographic text in such a way that it is clearly perceived by the user. The clustering is made "visual" by the vertical line to the left of the text. Wiegand (1989: 392) has also pointed out a similar example from the Dictionnaire $d u$ français vivant (DFV) by Davau et al. See also Smit (1996: 178-179).

\section{Bibliography}

\section{Dictionaries}

Davau, Maurice, Marcel Cohen and Maurice Lallemand. 1981. Dictionnaire du français vivant. New edition, completely revised and enlarged. Paris: Bordas.

Manchon, J.C. 19515. Cassell's French-English/English-French Dictionary. New York: Funk and Wagnalls Company.

Raponda-Walker, A. 1930-1934. Dictionnaire mpongwè-français, suivi d'éléments de grammaire. Metz: Imprimerie de la Libre Lorraine.

Raponda Walker, A. 1961. Dictionnaire français-mpongwè. Brazzaville: Imprimerie St Paul.

Raponda-Walker, A. 1995². Dictionnaire Français-Mpongwé. Libreville: Éditions Raponda-Walker. Classiques Africains.

\section{Other literature}

Benson, M., E. Benson and R.F. Ilson. 1986. Lexicographic Description of English. Amsterdam/Philadelphia: John Benjamins.

Bureau of the WAT. 1999. Study Guide of the Woordeboek van die Afrikaanse Taal (WAT). Unpublished Course Notes.

Gouws, R.H. 1996. Bilingual Dictionaries and Communicative Equivalence for a Multilingual Society. Lexikos 6: 15-31.

Gouws, R.H. 1999a. Equivalence Relations in Translation Dictionaries. Unpublished M.A. Course Notes.

Gouws, R.H. 1999b. Mediostructural Representation, Textual Condensation and User-orientation in the WAT X. Lexicographica 15: 4-37. 
Gouws, R.H. and D.J. Prinsloo. 1998. Cross-Referencing as a Lexicographic Device. Lexikos 8: 17-36.

Hartmann, R.R.K. 1989. Sociology of the Dictionary User: Hypothesis and Empirical Studies. Hausmann, F.J. et al. (Eds.). 1989-1991: 102-111.

Hausmann, F.J. and H.E. Wiegand. Component Parts and Structures of General Monolingual Dictionaries: A Survey. Hausmann, F.J. et al. (Eds.). 1989-1991: 328-360.

Hausmann, F.J. et al. 1989-1991. Wörterbücher. Ein internationales Handbuch zur Lexikographie/Dictionaries. An International Encyclopedia of Lexicography/Dictionnaires. Encyclopédie internationale de lexicographie. Berlin: De Gruyter.

Landau, S.I. 1991. Dictionaries: The Art and Craft of Lexicography. New York: C. Scribner's Sons/Cambridge: Oxford University Press.

Norri, J. 1996. Regional Labels in Some British and American Dictionaries. International Journal of Lexicography 9(1): 1-29.

Norri, J. 2000. Labelling of Derogatory Words in Some British and American Dictionaries. International Journal of Lexicography 13(2): 71-106.

Nyangone Assam, B. and P.A. Mavoungou. 2000. Lexicography in Gabon: A Survey. Lexikos 10: 252-274.

Raponda-Walker, A. 1998. Les langues du Gabon. Libreville: Éditions Raponda-Walker.

Raponda-Walker, A. 1933. Les néologismes dans les idiomes gabonais. Journal de la société des Africanistes 3(2): 305-314.

Smit, M. 1996. Wiegand's Metalexicography as a Framework for a Multilingual, Multicultural, Explanatory Music Education Dictionary for South Africa. Unpublished D.Litt. Thesis. Stellenbosch: University of Stellenbosch.

Wiegand, H.E. 1989. Aspekte der Makrostruktur im allgemeinen einsprachigen Wörterbuch: Alphabetische Anordnungsformen und ihre Probleme. Hausmann, F.J. et al. (Eds.). 1989-1991: 371-409.

Wiegand, H.E. 1999. Semantics and Lexicography. Selected Studies (1976-1996). Edited by Anntje Immken and Werner Wolski. Tübingen: Max Niemeyer.

Zgusta, L. 1987. Translational Equivalence in a Bilingual Dictionary. Dictionaries 9: 1-43. 